\title{
KARAKTERISTIK PENDERITA HEPATITIS C DI PROVINSI BALI TAHUN 2018 - 2019
}

\author{
Dwitya Arum Sari*, I Made Sutarga \\ Program Studi Sarjana Kesehatan Masyarakat, Fakultas Kedokteran, Universitas Udayana, \\ Jalan P.B. Sudirman, Dangin Puri Klod, Kec. Denpasar Bar., Kota Denpasar, Bali 80234
}

\begin{abstract}
ABSTRAK
Berdasarkan data WHO tahun 2015, sebanyak 1\% atau 71 juta orang di seluruh dunia terinfeksi virus hepatitis C (HCV). Berdasarkan hasil Riskesdas 2013, Provinsi Bali merupakan salah satu dari 5 Provinsi dengan prevalensi hepatitis C tertinggi di Indonesia. Penelitian yang dilakukan di Klinik VCT-CST RSUP Sanglah Denpasar menunjukkan sebanyak 83,3\% responden dengan anti HCV positif berjenis kelamin laki-laki dengan rerata usia responden 29 tahun. Selain faktor risiko medis, faktor lain seperti sosiodemografi juga memiliki peranan penting dalam perkembangan penyakit hepatitis C. Penelitian ini bertujuan untuk memperoleh informasi mengenai karakteristik penderita hepatitis C di Provinsi Bali tahun 2018 - 2019. Penelitian ini merupakan penelitian deskriptif kuantitatif dengan menggunakan rancangan cross sectional. Populasi target dari penelitian ini adalah penderita Hepatitis C yang menjalani pengobatan di Rumah Sakit Layanan Hepatitis C (RSUP Sanglah) Provinsi Bali tahun 2018 - 2019. Data yang diambil merupakan data penderita Hepatitis C yang tercatat dalam Sistem Informasi Hepatitis dan PISP (SIHEPI) Kementerian Kesehatan Republik Indonesia. Penelitian ini menunjukkan bahwa penderita hepatitis terbanyak berasal dari kelompok umur 31 - 40 tahun (34.23\%) serta di dominasi oleh laki-laki (70.27\%). Terdapat $17.12 \%$ penderita Hepatitis C yang memiliki status koinfeksi dan $62.16 \%$ penderita Hepatitis C mengalami sirosis. Sebanyak $69.63 \%$ penderita Hepatitis C telah menjalani pengobatan secara lengkap dengan $87.50 \%$ diantaranya dinyatakan SVR. Dari seluruh penderita Hepatitis C dalam penelitian ini, masih banyak (84.68\%) penderita yang tidak melakukan pemeriksaan SVR saat 3 atau 6 minggu setelah menjalani pengobatan.
\end{abstract}

Kata Kunci : Hepatitis C, VHC, karakteristik

\begin{abstract}
WHO estimates that in 2015 as many as $1 \%$ or 71 million people worldwide were infected with the hepatitis C virus (HCV). Based on the results of Riskesdas 2013, Bali Province is one of the 5 Provinces with the highest prevalence of hepatitis C in Indonesia. Research conducted at the VCT-CST Clinic at Sanglah Central General Hospital in Denpasar showed 83.3\% of respondents with anti-HCV positive were men with an average age of 29 years. Besides medical risk factors, other factors such as sociodemography also have an important role in the development of Hepatitis C. This research aims to obtain information about the characteristics of hepatitis $C$ sufferers in Bali Province in 2018 - 2019. This research is a descriptive quantitative study using a cross-sectional design. The target population of this study is Hepatitis $C$ sufferers who are undergoing treatment at the Hepatitis C Service Hospital (RSUP Sanglah) Bali Province in 2018 - 2019. The data taken is data on Hepatitis C sufferers recorded in the Hepatitis C Information System (SIHEPI) of the Ministry of Health of Republic Indonesia. This study shows that most hepatitis sufferers come from the age group 31-40 years $(34.23 \%)$ and are dominated by men $(70.27 \%)$. There are $17.12 \%$ of Hepatitis C sufferers who have co-infected status and $62.16 \%$ of Hepatitis C sufferers have cirrhosis. As many as $69.63 \%$ of people with Hepatitis C have undergone complete treatment with $87.50 \%$ of them declared SVR. Of all Hepatitis C sufferers in this study, there were still many $(84.68 \%)$ patients who did not undergo an SVR examination at 3 or 6 weeks after undergoing treatment.
\end{abstract}

Keywords : Hepatitis C, HCV, characteristics

\section{PENDAHULUAN}

Berdasarkan data WHO tahun 2015, sebanyak $1 \%$ atau 71 juta orang di seluruh dunia terinfeksi virus hepatitis C (HCV) dimana 399.000 diantaranya meninggal akibat sirosis atau hepatocellular carcinoma E-mail korespondensi : $\underline{\text { dr.sutarga@unud.ac.id }}$
(HCC) (WHO, 2018). Total prevalensi HCV global diperkirakan sebesar $2,5 \%$ atau 177,5 juta orang dengan prevalensi 2,9\% di Africa, 1,3\% di Amerika, 2,8\% di Asia, 1,8\% di Australia dan $1,8 \%$ di Eropa (Petruzziello et al., 2016). Mohd Hanafiah 
dkk. menemukan bahwa prevalensi infeksi $\mathrm{HCV}$ tertinggi di Asia Tenggara pada tahun 2005 berada pada kelompok usia 50 - 64 tahun sebesar $4.7 \%$.

Belum tersedianya vaksin yang efektif guna pencegahan infeksi HCV telah menjadi tantangan besar, terutama di Indonesia, yang merupakan negara berkembang dengan jumlah penduduk terbesar keempat di dunia (Dwi Hadya Jayani, 2019). Riset Kesehatan Dasar (Riskesdas) 2013 menyebutkan, prevalensi orang yang terinfeksi hepatitis C 2,5\% atau sekitar 5 juta orang di Indonesia. Lima Provinsi dengan prevalensi tertinggi yaitu Kepulauan Riau (21,3\%), Sumatera Barat $(7.4 \%)$, Bali $(6,4 \%)$, Banten $(6,0 \%)$ dan Kalimantan Timur (5,2\%).

Penelitian Wulandari dan Mulyandari pada tahun 2016 menunjukkan hasil skrining hepatitis $C$ pada darah donor di unit donor darah PMI Provinsi Bali menunjukkan $0,4 \%$ atau sebanyak 78 dari 17.526 donor memiliki hasil reaktif terhadap Anti HCV. Penelitian lainnya yang dilakukan oleh Somia, dkk di Klinik VCT-CST RSUP Sanglah Denpasar menunjukkan sebanyak $83,3 \%$ responden dengan anti $\mathrm{HCV}$ positif berjenis kelamin laki-laki dengan rerata usia responden 29 tahun.

Faktor risiko utama hepatitis C seperti penggunaan jarum suntik yang tidak steril, hemodialisis, hubungan seks berisiko tinggi, adanya komorbiditas (infeksi Human Immunodeficiency Virus/HIV), transfusi dan prosedur medis lain berkontribusi besar pada timbulnya penyakit ini. Selain faktor risiko medis utama tersebut, faktor lain seperti E-mail korespondensi : dr.sutarga@unud.ac.id sosiodemografi juga memiliki peranan penting dalam perkembangan penyakit hepatitis C (Dany and Sarwo Handayani, 2018).

Seperti Hepatitis lainnya, Hepatitis C juga dapat berkembang menjadi akut dan kronis. Penelitian yang mengevaluasi perjalanan alamiah penyakit menunjukkan di antara penderita Hepatitis C kronis sekitar 55\% - 85\% akan berkembang menjadi penyakit hati kronis. Sebanyak $15 \%-30 \%$ akan berkembang menjadi sirosis dan $1 \%-5 \%$ diperkirakan akan meninggal akibat sirosis dan hepatocellular carcinoma (HCC) (Khullar and Firpi, 2015).

Hingga saat ini belum ada data mengenai karakteristik penderita hepatitis C di Provinsi Bali, oleh karena itu peneliti tertarik untuk meneliti karakteristik dari penderita hepatitis C di Provinsi Bali tahun 2018 - 2019. Penelitian ini dianggap perlu dalam memberikan gambaran umum mengenai karakteristik penderita hepatitis C kepada pemegang kebijakan serta pelayanan kesehatan guna meningkatkan pelayanan kesehatan kepada penderita hepatitis $C$ di Provinsi Bali.

Hepatitis C merupakan masalah kesehatan di dunia temasuk Indonesia. Sekitar 500 ribu kasus baru dengan 160 ribu kematian akibat hepatitis $\mathrm{C}$ terjadi setiap tahunnya. Berdasarkan hasil Riskesdas 2013, Provinsi Bali merupakan salah satu dari 5 Provinsi dengan prevalensi hepatitis $\mathrm{C}$ tertinggi di Indonesia.

Hepatitis C yang tidak ditangani dapat berkembang menjadi hepatocellular carcinoma yang fatal dan menjadi indikasi untuk dilakukan transpantasi hati. Oleh 
karena itu, peneliti tertarik dalam menggambarkan karakteristik penderita Hepatitis C di Provinsi Bali tahun 2018 2019.

\section{METODE PENELITIAN}

Penelitian ini menggunakan rancangan cross sectional deskriptif kuantitatif untuk menggambarkan karakteristik penderita hepatitis C di Provinsi Bali tahun 2018 - 2019. Sampel dalam penelitian ini adalah penderita Hepatitis C di Provinsi Bali yang telah menjalani pengobatan pada tahun 2018 2019.

Sampel dalam penelitian ini dipilih dengan kriteria inklusi yaitu penderita Hepatitis C di Provinsi Bali tahun 2018 2019 yang telah menjalani pengobatan di Rumah Sakit Layanan Hepatitis C (RSUP Sanglah) dan tercatat dalam Sistem Informasi Hepatitis dan PISP (SIHEPI) Kementerian Kesehatan Republik Indonesia. dan kriteria ekslusi yaitu penderita hepatitis $\mathrm{C}$ dengan data yang tidak lengkap dan/atau penderita yang mengulang pengobatan hepatitis C (restart).

Besar sampel minimal yang dibutuhkan dalam penelitian ini sebanyak 93 sampel. Data yang dikumpulkan dalam penelitian ini merupakan data sekunder berupa data umur, jenis kelamin, status koinfeksi, status sirosis, faktor risiko, rejimen Hepatitis $\mathrm{C}$, kelengkapan terapi dan akhir pengobatan penderita Hepatitis C.

Pemilihan sampel dalam penelitian ini menggunakan teknik total sampling dengan mengambil seluruh data penderita Hepatitis C yang menjalani pengobatan di Rumah Sakit Layanan Hepatitis C (RSUP E-mail korespondensi : dr.sutarga@unud.ac.id
Sanglah) Provinsi Bali tahun 2018 - 2019.

Data yang diambil merupakan data penderita Hepatitis C yang tercatat dalam Sistem Informasi Hepatitis dan PISP (SIHEPI) Kementerian Kesehatan Republik Indonesia.

HASIL

\section{Karakteristik Penderita Hepatitis C}

Tabel 1. Karakteristik penderita Hepatitis C

\begin{tabular}{lcc}
\hline Karakteristik & $\begin{array}{c}\text { Frekuensi } \\
(\mathbf{n})\end{array}$ & $\begin{array}{c}\text { Persen } \\
\mathbf{( \% )}\end{array}$ \\
\hline Umur (tahun) & & \\
$<31$ & 4 & 3.60 \\
$31-40$ & 38 & 34.23 \\
$41-50$ & 26 & 23.42 \\
$51-60$ & 12 & 10.81 \\
$>60$ & 31 & 27.93 \\
\hline Jenis kelamin & & \\
Laki-laki & 78 & 70.27 \\
Perempuan & 33 & 29.73 \\
\hline
\end{tabular}

Karakteristik penderita Hepatitis C dalam penelitian ini terdiri dari umur dan jenis kelamin. Tabel 1 menunjukkan variabel umur terbagi kedalam lima kategori yaitu $<31$ tahun berjumlah 4 orang (3.6\%), 31 - 40 tahun 38 orang (34.23\%), 41 - 50 tahun sebanyak 26 orang (23.42\%), 51 - 60 tahun sebanyak 12 orang (10.81\%), dan $>60$ tahun sebanyak 31 orang $(27.93 \%)$. Usia termuda dari penderita Hepatitis C yaitu 24 tahun dan tertua yaitu 83 tahun.

Berdasarkan jenis kelamin, penderita Hepatitis C di Provinsi Bali terbanyak berjenis kelamin laki-laki yaitu 78 orang $(70.27 \%)$ dan sisanya 33 orang $(29.73 \%)$ perempuan. 


\begin{tabular}{lcc}
$\begin{array}{l}\text { Status Koinfeksi } \\
\text { Penderita Hepatitis C }\end{array}$ & Status & Sirosis \\
$\begin{array}{l}\text { Tabel 2. Status } \\
\text { Hepatitis C }\end{array}$ & \\
Hoinfeksi & penderita \\
\hline Status koinfeksi & Frekuensi & Persen \\
& $(\mathbf{n})$ & $\mathbf{( \% )}$ \\
\hline Koinfeksi & 19 & 17.12 \\
Monoinfeksi & 92 & 82.88 \\
Total & $\mathbf{1 1 1}$ & $\mathbf{1 0 0}$ \\
\hline
\end{tabular}

Koinfeksi merupakan infeksi stimulan dari dua virus. Berdasarkan hasil pada tabel 2 diketahui sebanyak 19 orang (17.12\%) penderita Hepatitis C di Provinsi Bali tahun 2018 - 2019 terinfeksi virus lain selain Hepatitis C (koinfeksi) sedangkan 92 orang $(82.88 \%)$ hanya terinfeksi virus Hepatitis C (monoinfeksi).

Tabel 3. Status sirosis penderita Hepatitis C

\begin{tabular}{lcc}
\hline Status sirosis & $\begin{array}{c}\text { Frekuensi } \\
\text { (n) }\end{array}$ & $\begin{array}{c}\text { Persen } \\
\mathbf{( \% )}\end{array}$ \\
\hline Sirosis & 69 & 62.16 \\
Tidak sirosis & 42 & 37.84 \\
Total & $\mathbf{1 1 1}$ & $\mathbf{1 0 0}$ \\
\hline
\end{tabular}

Hasil analisis deskriptif dari status sirosis dari penderita Hepatitis C di Provinsi Bali dapat dilihat dalam tabel 3. Sebanyak 69 orang $(62.16 \%)$ mengalami sirosis dan 42 orang (37.84\%) tidak mengalami sirosis pada hati.

Tabel 4. Hasil bivariat karakteristik dengan status koinfeksi penderita Hepatitis C

\begin{tabular}{lcccc}
\hline \multirow{2}{*}{ Karakteristik Responden } & \multicolumn{2}{c}{ Status koinfeksi } & \multirow{2}{*}{ Total (\%) } & p \\
\cline { 2 - 3 } & Koinfeksi (\%) & Monoinfeksi (\%) & & \\
\cline { 2 - 3 } Umur (tahun) & $0(0.00)$ & $4(100.00)$ & $4(100.00)$ & \\
$31-40$ & $13(34.21)$ & $25(65.79)$ & $38(100.00)$ & 0.3546 \\
$41-50$ & $5(19.23)$ & $21(80.77)$ & $26(100.00)$ & \\
$51-60$ & $0(0.00)$ & $12(100.00)$ & $12(100.00)$ & \\
$>60$ & $1(3.23)$ & $30(96.77)$ & $31(100.00)$ & \\
\hline Jenis kelamin & & & & \\
Laki-laki & $18(23.08)$ & $60(76.92)$ & $78(100.00)$ & 0.0104 \\
Perempuan & $1(3.03)$ & $32(96.97)$ & $33(100.00)$ & \\
\hline
\end{tabular}

Tabel 4. menunjukkan karakteristik penderita yaitu umur dan jenis kelamin yang dihubungkan dengan status koinfeksi penderita Hepatitis C. Berdasarkan tabel 4, kelompok umur terbanyak yang mengalami koinfeksi yaitu pada kelompok umur 31 - 40 tahun yaitu $34.21 \%, 41-50$ tahun $19.23 \%$, dan $>60$ tahun $3.23 \%$. Uji Chi-Square menunjukkan variabel umur tidak memiliki hubugan yang signifikan 
dengan status koinfeksi dengan nilai $\mathrm{p}=$ $0.3546(95 \% \mathrm{CI}=0)$.

Berdasarkan variabel jenis kelamin, jenis kelamin yang lebih banyak mengalami koinfeksi yaitu laki-laki sebesar $23.08 \%$ sedangkan perempuan $3.03 \%$.
Setelah dilakukan uji Chi-Square diketahui bahwa variabel jenis kelamin memiliki hubungan signifikan dengan status koinfeksi penderita Hepatitis C dengan nilai $p=0.0104(95 \% \mathrm{CI}=0.18-0.94)$.

Tabel 5. Hasil bivariat karakteristik dengan status koinfeksi penderita Hepatitis C

\begin{tabular}{lcccc}
\hline \multirow{2}{*}{ Karakteristik Responden } & \multicolumn{2}{c}{ Status sirosis } & \multirow{2}{*}{ Total (\%) } & p \\
\cline { 2 - 3 } Umur (tahun) & Sirosis (\%) & Tidak sirosis (\%) & & \\
$<31$ & $1(25.00)$ & $3(75.00)$ & $4(100.00)$ & \\
$31-40$ & $18(47.37)$ & $20(52.63)$ & $38(100.00)$ & 0.1185 \\
$41-50$ & $18(69.23)$ & $8(30.77)$ & $26(100.00)$ & \\
$51-60$ & $11(91.67)$ & $1(8.33)$ & $12(100.00)$ & \\
$>60$ & $21(67.74)$ & $10(32.26)$ & $31(100.00)$ & \\
\hline Jenis kelamin & & & & \\
Laki-laki & $46(58.97)$ & $32(41.03)$ & $78(100.00)$ & 0.2870 \\
Perempuan & $23(69.70)$ & $10(30.30)$ & $33(100.00)$ & \\
\hline
\end{tabular}

Tabel 5. menunjukkan karakteristik penderita yaitu umur dan jenis kelamin dihubungkan dengan status sirosis penderita Hepatitis C. Pada variabel umur, kelompok umur tebanyak yang mengalami sirosis adalah kelompok umur 51 - 60 tahun sebesar $91.67 \%, 41$ - 50 tahun sebesar $69.23 \%$, >60 tahun sebesar $67.74 \%, 31-40$ tahun $47.37 \%$, dan $<31$ tahun $25.00 \%$. Setelah dilakukan uji Chi-Square diketahui variabel umur tidak memiliki hubungan yang signifikan dengan status sirosis penderita Hepatitis $\mathrm{C}$ dengan nilai $\mathrm{p}=$ $0.1185(95 \% \mathrm{CI}=0.46-13.96)$.

Berdasarkan variabel jenis kelamin penderita Hepatitis C yang mengalami sirosis adalah jenis kelamin perempuan sebesar $69.70 \%$ sedangkan laki-laki 58.97\%. Hasil uji Chi-Square menunjukkan tidak adanya hubungan yang signifikan antara variabel jenis kelamin dengan status sirosis penderita dengan nilai $\mathrm{p}=0.2870(95 \% \mathrm{CI}=$ $0.88-1.58)$.

Tabel 6. Hasil bivariat status koinfeksi dengan status sirosis penderita Hepatitis C

\begin{tabular}{lcccc}
\hline \multirow{2}{*}{ Status koinfeksi } & \multicolumn{2}{c}{ Status sirosis } & \multirow{2}{*}{ Total (\%) } & \multirow{2}{*}{$\mathbf{P}$} \\
\cline { 2 - 3 } & Sirosis (\%) & Tidak sirosis (\%) & & \\
\hline Koinfeksi & $8(42.11)$ & $11(57.89)$ & $19(100.00)$ & \multirow{2}{*}{0.0477} \\
Monoinfeksi & $61(66.30)$ & $31(33.70)$ & $92(100.00)$ & \\
\hline
\end{tabular}


Berdasarkan tabel 6, sebanyak 8 orang $(42.11 \%)$ penderita Hepatitis C yang memiliki koinfeksi juga mengalami sirosis sedangkan 11 orang (57.89\%) lainnya tidak mengalami sirosis. Dari kelompok yang tidak memiliki koinfeksi (monoinfeksi) terdapat 61 orang $(66.30 \%)$ mengalami sirosis dan 31 orang (33.70\%) tidak mengalami sirosis. Setelah dilakukan uji Chi-Square diketahui bahwa variabel status koinfeksi memiliki hubungan yang signifikan dengan status sirosis penderita Heapatitis C dengan nilai p $=0.0477$ (95\% $\mathrm{CI}=0.19-1.01)$.

\section{Pengobatan Penderita Hepatitis C}

Tabel 7. Rejimen penderita Hepatitis C

\begin{tabular}{lcc}
\hline Rejimen & Frekuensi (n) & Persen (\%) \\
\hline SOF + DAC & 100 & 90.09 \\
SOF + SIM & 8 & 7.21 \\
SOF + RBV & 2 & 1.80 \\
ELB + GRA & 1 & 0.90 \\
Total & $\mathbf{1 1 1}$ & $\mathbf{1 0 0}$ \\
\hline
\end{tabular}

Rejimen Hepatitis C merupakan obat yang digunakan untuk pengobatan penderita Hepatitis C. Tabel 7. menunjukkan sebanyak 100 orang (90.09\%) penderita Hepatitis C menggunakan sofosbuvir dikombinasikan dengan daclatasvir, 8 orang (7.21\%) sofosbuvir dikombinasikan dengan simeprevir, 2 orang $(1.80 \%)$ sofosbuvir dikombinasikan dengan ribavirin, dan 1 orang (0.90\%) menggunakan elbasvir dengan grazoprevir.
Tabel 8. Kelengkapan terapi penderita Hepatitis C

\begin{tabular}{lcc}
\hline $\begin{array}{l}\text { Kelengkapan } \\
\text { terapi }\end{array}$ & $\begin{array}{c}\text { Frekuensi } \\
\text { (n) }\end{array}$ & $\begin{array}{c}\text { Persen } \\
\text { (\%) }\end{array}$ \\
\hline Lengkap & 77 & 69.63 \\
Tidak lengkap & 34 & 30.63 \\
Total & $\mathbf{1 1 1}$ & $\mathbf{1 0 0}$ \\
\hline
\end{tabular}

Penderita Hepatitis C dikatakan mendapatkan terapi lengkap apabila menjalani pengobatan sesuai dengan durasi pengobatan yang seharusnya. Berdasarkan hasil analisis deskriptif pada tabel 8, diketahui sebanyak 77 orang $(69.63 \%)$ penderita menerima terapi secara lengkap dan 34 orang (30.63\%) tidak menerima terapi secara lengkap.

Tabel 9. Akhir pengobatan penderita Hepatitis C

\begin{tabular}{lcc}
\hline $\begin{array}{l}\text { Akhir } \\
\text { pengobatan }\end{array}$ & $\begin{array}{c}\text { Frekuensi } \\
\text { (n) }\end{array}$ & $\begin{array}{c}\text { Persen } \\
\text { (\%) }\end{array}$ \\
\hline Tidak diperiksa & 94 & 84.68 \\
SVR & 16 & 14.41 \\
Non SVR & 0 & 0 \\
Meninggal & 1 & 0.90 \\
Total & $\mathbf{1 1 1}$ & $\mathbf{1 0 0}$ \\
\hline
\end{tabular}

Akhir dari pengobatan Hepatitis C adalah SVR yang dilakukan 3 atau 6 minggu setelah menjalani pengobatan. Berdasarkan tabel 9. diketahui bahwa sebanyak 94 orang (84.68\%) tidak diperiksa, 16 orang $(14.41 \%)$ telah SVR, dan 1 orang (0.90\%) meninggal.

Tabel 10. Hasil bivariat akhir pengobatan dengan kelengkapan terapi penderita Hepatitis C

\begin{tabular}{|c|c|c|c|c|c|}
\hline \multirow{2}{*}{ Kelengkapan Terapi } & \multicolumn{4}{|c|}{ Kelengkapan Terapi } & \multirow{2}{*}{ Total $(\%)$} \\
\hline & Tidak & SVR (\%) & Non & Meninggal & \\
\hline
\end{tabular}




\begin{tabular}{|c|c|c|c|c|c|}
\hline & diperiksa (\% & & SVR (\%) & $(\%)$ & \\
\hline Lengkap & $63(81.82)$ & $14(18.18)$ & $0(0.00)$ & $0(0.00)$ & 77 (100.00) \\
\hline Tidak Lengkap & 31 (91.18) & $2(5.88)$ & $0(0.00)$ & $1(2.94)$ & $34(100.00)$ \\
\hline Total & $94(84.68)$ & 16 (14.41) & $0(0.00)$ & $1(0.90)$ & $111(100.00)$ \\
\hline
\end{tabular}

Tabel 10 menunjukkan hasil tabulasi silang dari kelengkapan terapi dengan akhir pengobatan penderita Hepaitis C di Provinsi Bali. Berdasarkan tabel diatas, dari seluruh penderita yang mendapatkan terapi lengkap sebanyak 14 orang (18.18\%) dinyatakan SVR dan 63 orang $(81.82 \%)$ tidak melakukan pemeriksaan SVR pada 12/24 minggu setelah pengobatan. Sedangkan dari kelompok yang tidak menerima terapi secara lengkap sebanyak 31 orang (91.18\%) penderita tidak melakukan pemeriksaan SVR, 2 orang (5.88\%) telah dinyatakan SVR dan 1 orang (2.94\%) lainnya meninggal.

\section{DISKUSI}

\section{Karakteritik Penderita Hepatitis C}

Karakteristik penderita Hepatitis C dalam penelitian ini terdiri atas umur dan jenis kelamin. Petruzziello, dkk dalam penelitiannya membagi umur penderita Hepatitis C menjadi 5 kategori yaitu $<31$ tahun, $31-40$ tahun, $41-50$ tahun, $50-60$ tahun, dan $>60$ tahun. Hasil analisis deskriptif pada penelitian ini menunjukkan penderita Hepatitis C di Provinsi Bali terbanyak berada pada kelompok umur 31 - 40 tahun yaitu 38 orang (34.23\%). Spach (2017) menunjukkan penderita Hepatitis C terbanyak di Amerika berasal dari kelompok umur $20-29$ tahun diikuti dengan umur 30 - 39 tahun.

Hasil penelitian ini berbeda dengan hasil penelitian Fadlalla, dkk (2015) yang mendapati angka kejadian Hepatitis C yang meningkat pada kelompok umur diatas 40 tahun. Sejalan dengan penelitian Fadlalla, dkk, penelitian Monica (2017) pada pasien Hepatitis C di RSUP Adam Malik Medan yang menunjukkan umur pasien Hepatitis $C$ terbanyak berada pada kelompok umur 50 - 59 tahun. Penelitian lainnya yang dilakukan oleh Petruzziello, dkk yang menunjukkan jumlah penderita Hepatitis C terbanyak pada kelompok umur diatas 60 tahun.

Penderita Hepatitis C di Provinsi Bali didominasi oleh laki-laki sebanyak 78 orang (70.27\%). Penelitian terdahulu lainnya juga menunjukkan hasil yang sejalan seperti pada penelitian Surjadi, dkk (2011) yang mendapati jenis kelamin lakilaki mendominasi penderita Hepatitis C di rumah sakit umum San Francisco. Butterfield, dkk (2003) menyatakan lakilaki memiliki tingkat infeksi Hepatitis C dua kali lebih besar dari perempuan. Hal ini disebabkan karena laki-laki memiliki tingkat perilaku risiko Hepatitis C lebih tinggi dibandingkan dengan perempuan.

\section{Status Koinfeksi dan Status Sirosis Penderita Hepatitis C}

Hasil penelitian ini menunjukkan sebanyak 19 orang (17.12\%) penderita Hepatitis C di Provinsi Bali mengalami koinfeksi. Koinfeksi yang ditemukan pada penderita Hepatitis C hanya koinfeksi dengan HIV dan tidak ditemukan koinfeksi 
dengan penyakit lainnya seperti Hepatitis B maupun TB. Maier dan $\mathrm{Wu}$ menyebutkan diantara $10 \%$ orang dengan $\mathrm{HCV}$ positif juga memiliki HIV yang positif dan diantara $25 \%$ orang dengan HIV positif juga memiliki HCV yang positif. Hernandez dan Sherman menjelaskan penderita Hepatitis C dengan koinfeksi HIV memiliki perkembangan yang lebih cepat serta menyebabkan efek samping pada pengobatan.

Berdasarkan hasil tabulasi silang, umur dengan status koinfeksi penderita Hepatitis C diketahui penderita Hepatitis C dari kelompok umur 31 - 40 tahun merupakan kelompok umur tebanyak mengalami koinfeksi dan jenis kelamin terbanyak mengalami koinfeksi adalah laki-laki. Berdasarkan hasil uji Chi-Square variabel umur dengan status koinfeksi didapatkan nilai $\mathrm{p}>0.05$ yang artinya variabel umur tidak memiliki hubungan yang signifikan dengan status koinfeksi. Sedangkan untuk variabel jenis kelamin didapatkan nilai $p \quad<0.05$ yang menunjukkan adanya hubungan antara jenis kelamin dengan status koinfeksi.

Dari 111 sampel dalam penelitian ini, sebanyak 69 orang (62.16\%) mengalami sirosis. Toshikuni, Arisawa dan Tsutsumi menyatakan prevalensi terjadinya sirosis hati pada penderita hepatitis C kronik sebesar 20 - 30\%. Jacobson, dkk menjelaskan berdasarkan 111 penelitian yang menganalisis riwayat alami $\mathrm{HCV}$ memeperkirakan prevalensi sirosis 20 tahun setelah infeksi sebesar 16\% (95\% CI : $14-90 \%)$. Jacobson, dkk juga menyebutkan terdapat beberapa faktor yang mempengaruhi perkembangan fibrosis E-mail korespondensi : dr.sutarga@unud.ac.id diantaranya umur, jenis kelamin, genotipe $\mathrm{HCV}$, status koinfeksi serta konsumsi alkohol.

Selain faktor-faktor tersebut, Younossi, Birerdinc dan Henry juga menambahkan bahwa perbedaan geografis dalam tingkat perkembangan penyakit Hepatitis C juga harus dipertimbangkan. Berdasarkan hasil tabulasi silang umur dan jenis kelamin pada penelitian ini, kelompok umur terbanyak yang mengalami sirosis adalah kelompok umur 51 - 60 tahun dan jenis kelamin wanita. Setelah dilakukan uji Chi-Square didapatkan nilai $\mathrm{p}>0.05$ yang berarti baik variabel umur maupun jenis kelamin tidak memiliki hubungan dengan status sirosis penderita Hepatitis C.

Hasil tabulasi silang antara status koinfeksi dengan status sirosis penderita Hepatitis C diketahui bahwa pendeita Hepatitis $C$ dengan status sirosis terbanyak berasal dari kelompok penderita yang tidak memiliki koinfeksi (monoinfeksi). Berdasarkan hasil uji Chi-Square didapatkan nilai $\mathrm{p}<0.05$ yang menunjukkan bahwa status koinfeksi memiliki hubungan dengan status sirosis pada penderita Hepatitis C.

Penelitian yang dilakukan oleh Butt, dkk mendapati dari seluruh penderita Hepatitis C dengan sirosis sebanyak 29.3\% merupakan penderita Hepatitis C dengan koinfeksi Hepatitis B dan 22.5\% penderita monoinfeksi Hepatitis C. Penelitian lainnya pada pasien Hepatitis $C$ dengan dan tanpa koinfeksi HIV yang dilakukan oleh Martinez-Sierra, dkk mendapatkan sebanyak $22 \%$ pasien yang memiliki sisrosis merupakan pasien dengan 
koinfeksi HIV/HCV sedangkan 6\% berasal dari kelompok yang tidak terinfeksi HIV.

\section{Pengobatan Penderita Hepatitis C}

Sofosbuvir dan daclatasvir merupakan kombinasi obat yang digunakan oleh hampir seluruh penderita Hepatitis C di Provinsi Bali yaitu sebanyak 100 orang $(90.09 \%)$. Kombinasi sofosbuvir dan daclatasvir merupakan rejimen IFN-Free fase II yang memiliki tingkat SVR berkisar 89\% - 98\% (Asselah, 2014). Pol, ValletPichard dan Corouge menyatakan kombinasi sofosbuvir dan daclatasvir merupakan rejimen yang sangat efisien dalam pengobatan pasien dengan genotipe 1, 2 dan 3 bahkan pada pasien yang "sulit diobati". Kombinasi sofosbuvir dan daclatasvir ini dapat diberikan dengan/tanpa ribavirin tergantung pada kondisi penderita Hepatitis C.

Hasil penelitian Abdel-Aziz, dkk menunjukkan keamanan terapi sofosbuvir dan daclatasvir dengan/tanpa ribavirin. Pasien yang menerima terapi menggunakan sofosbuvir dan daclatasvir tanpa ribavirin tidak ditemukan efek samping sedangkan pada pasien dengan ribavirin terjadi penurunan kadar bilirubin dan hemoglobin. Hal ini sejalan dengan pernyataan Pol, Vallet-Pichard dan Corouge bahwa ribavirin tidak diperlukan untuk setiap rejimen DAA oral seperti sofosbuvir dan daclatasvir mengingat risiko anemia dan teratogenisitas yang dapat ditimbulkan.

Berdasarkan kelengkapan terapi sebanyak 77 orang (69.63\%) telah mendapatkan terapi secara lengkap atau sesuai dengan durasi pengobatan yang E-mail korespondensi : dr.sutarga@unud.ac.id ditentukan dokter. Dari 111 sampel dalam penelitian ini, sebanyak 94 orang $(84.68 \%)$ penderita Hepatitis C tidak melakukan pemeriksaan SVR pada minggu ke 12/24 dari akhir pengobatannya. Berdasarkan hasil tabulasi silang diketahui bahwa dari seluruh penderita yang mendapatkan terapi lengkap hanya 14 orang (18.18\%) dinyatakan SVR dan dari kelompok yang tidak menerima terapi secara lengkap sebanyak 1 orang (2.94\%) meninggal dunia. Penelitian Tsertsvadze, dkk dalam penelitiannya mengenai hasil pengobatan Hepatitis C di Gerogia mendapatkan sebanyak 5079 orang (69.35\%) menjalani terapi secara lengkap dimana sebanyak 4170 orang $(82.1 \%)$ dinyatakan SVR. Penelitian tersebut juga menemukan sebanyak 521 orang $(7.10 \%)$ menghentikan pengobatan Hepatitis $\mathrm{C}$ dengan penyebab paling umum adalah kematian (48.8\%), berhenti berobat $(19.6 \%)$ dan lost to follow up $(15.9 \%)$.

\section{SIMPULAN}

Berdasarkan karakteristik penderita dalam penelitian ini yaitu umur dan jenis kelamin, kelompok umur terbanyak penelitian berada pada rentang umur 31 40 tahun yaitu $34.23 \%$. Sedangkan sebanyak $70.27 \%$ penderita Hepatitis C dalam penelitian ini berjenis kelamin lakilaki.

Penderita Hepatitis C yang memiliki koinfesi sebanyak $17.12 \%$. Penderita dengan koinfeksi paling banyak berasal dari kelompok umur 31 - 40 tahun yaitu $34.21 \%$ sedangkan untuk jenis kelamin terbanyak adalah laki-laki yaitu $23.08 \%$. Sebanyak $62.16 \%$ penderita 
Hepatitis C mengalami sirosis dengan penderita terbanyak berasal dari kelompok umur 51 - 60 tahun (91.67\%) dan jenis kelamin perempuan $(69.70 \%)$.

Kombinasi sofosbuvir dengan daclatasvir merupakan rejimen Hepatitis C yang paling banyak digunakan oleh penderita Hepatitis C (90.09\%). Sebanyak 69.63\% penderita Hepatitis C telah menjalani pengobatan secara lengkap dengan $87.50 \%$ diantaranya dinyatakan SVR. Dari seluruh penderita Hepatitis C dalam penelitian ini, masih banyak $(84.68 \%)$ penderita yang tidak melakukan pemeriksaan SVR.

\section{SARAN}

Evaluasi kepada pasien serta tenaga kesehatan perlu dilakukan sehingga dapat mengurangi jumlah penderita yang lost follow-up atau tidak memeriksakan diri setelah selesai menjalani pengobatan. Selain itu, peningkatan edukasi kepada masyarakat guna meningkatkan pengetahuan serta pemahaman masyarakat terhadap pentingnya menyelesaikan pengobatan.

Perlunya penelitian lebih lanjut mengenai faktor-faktor yang berhubungan dengan Hepatitis C mengingat masih kurangnya penelitian mengenai faktorfaktor penyebab Hepatitis C di Indonesia.

\section{UCAPAN TERIMA KASIH}

Ucapan terima kasih kepada Dekan FK Unud, Koordinator PSSKM FK Unud, Koordinator Peminatan Epidemiologi PSSKM FK Unud, pembimbing skripsi serta semua pihak yang telah banyak memberikan bantuan dalam penelitian ini. E-mail korespondensi : dr.sutarga@unud.ac.id

\section{DAFTAR PUSTAKA}

Abdel-Aziz, A. M. et al. (2018) 'Effect of Sofosbuvir Plus Daclatasvir in Hepatitis C Virus Genotype-4 Patients: Promising Effect on Liver Fibrosis', Journal of Clinical and Experimental Hepatology. INASL, 8(1), pp. 15-22. doi: 10.1016/j.jceh.2017.06.006.

Asselah, T. (2014) 'Daclatasvir plus sofosbuvir for HCV infection: An oral combination therapy with high antiviral efficacy', $N$ Engl J Med, 370(3), pp. 211-221. doi: 10.1056/NEJMoa1306218.

Butt, A. A. et al. (2019) 'Liver Fibrosis Progression and Mortality in Hepatitis B- and C-Coinfected Persons Treated With Directly Acting Antiviral Agents: Results From ERCHIVES', Clinical Infectious Diseases, $(\mathrm{X} \times \mathrm{Xxxx})$, pp. 1-3. doi: 10.1093/cid/ciz1097.

Butterfield, M. I. et al. (2003) 'Gender Differences in Hepatitis C Infection and Risks Among Persons with Severe Mental Ilness', Psychiatric Services, 54(6), pp. 848-853. doi: 10.1176/appi.ps.54.6.848.

Dany, F. and Sarwo Handayani (2017) 'Seroprevalensi Hepatitis C pada Populasi Perkotaan dan Perdesaan di Indonesia Tahun 2013: Kajian Determinan Sosiodemografi, Lingkungan, Pejamu, dan Komorbiditas (Analisis Lanjut Riskesdas 2013)', Media Litbangkes, 27(4), pp. 197-208. doi: 10.22435/mpk.v27i4.6267.197-208.

Dwi Hadya Jayani (2019) 2020, Penduduk Indonesia Terbesar Keempat Dunia I Databoks. Available at: https://databoks.katadata.co.id/data publish/2019/12/16/2020-penduduk- 
indonesia-terbesar-keempat-dunia (Accessed: 11 March 2020).

Fadlalla, F. A. et al. (2015) 'The Epidemiology of Hepatitis C Virus in the Maghreb Region: Systematic Review and Meta-Analyses', PLoS ONE. Public Library of Science, 10(3). doi: 10.1371/journal.pone.0121873.

Hernandez, M. D. and Sherman, K. E. (2011) 'HIV/hepatitis C coinfection natural history and disease progression', Current Opinion in HIV and AIDS. NIH Public Access, pp. 478-482. doi: 10.1097/COH.0b013e32834bd365.

Jacobson, I. M. et al. (2010) 'STATE OF THE ART Prevalence and Challenges of Liver Diseases in Patients With Chronic Hepatitis C Virus Infection'. doi: 10.1016/j.cgh.2010.06.032.

Khullar, V. and Firpi, R. J. (2015) 'Hepatitis $C$ cirrhosis: New perspectives for diagnosis and treatment', World Journal of Hepatology. Baishideng Publishing Group Co, 7(14), pp. 1843-1855. doi: 10.4254/wjh.v7.i14.1843.

Maier, I. and Wu, G. Y. (2002) 'Hepatitis C and HIV co-infection: A review', World Journal of Gastroenterology. WJG Press, pp. 577-579. doi: 10.3748/wjg.v8.i4.577.

Martinez-Sierra, C. et al. (2003) Progression of Chronic Hepatitis C to Liver Fibrosis and Cirrhosis in Patients Coinfected with Hepatitis C Virus and Human Immunodeficiency Virus, Clinical Infectious Diseases. Available at: https://academic.oup.com/cid/articl e-abstract/36/4/491/441510

(Accessed: 15 July 2020).

Mohd Hanafiah, K. et al. (2013) 'Global epidemiology of hepatitis $C$ virus infection: New estimates of age- specific antibody to $\mathrm{HCV}$ seroprevalence', Journal of Hepatology. John Wiley \& Sons, Ltd, pp. 1333-1342. doi: 10.1002/hep.26141.

Monica, R. (2017) Profil Pasien Hepatitis C Di Rsup Haji Adam Malik Medan. Universitas Sumatera Utara.

Petruzziello, A. et al. (2016) 'Global epidemiology of hepatitis $C$ virus infection: An up-date of the distribution and circulation of hepatitis C virus genotypes', World Journal of Gastroenterology. Baishideng Publishing Group Co., Limited, pp. 7824-7840. doi: 10.3748/wjg.v22.i34.7824.

Petruzziello, A. et al. (2019) 'Nine-year distribution pattern of hepatitis $C$ virus (HCV) genotypes in Southern Italy', PLOS ONE. Edited by Y. E. Khudyakov. Public Library of Science, 14(2), p. e0212033. doi: 10.1371/journal.pone.0212033.

Pol, S., Vallet-Pichard, A. and Corouge, M. (2016)

'Daclatasvir\&ndash;sofosbuvir combination therapy with or without ribavirin for hepatitis $\mathrm{C}$ virus infection: from the clinical trials to real life', Hepatic Medicine: Evidence and Research. Dove Medical Press Ltd., p. 21. doi: 10.2147/hmer.s62014.

Riskesdas (2013) 'Riset Kesehatan Dasar $2013^{\prime}$.

Somia, A. et al. (2010) 'Karakteristik Pasien Ko-Infeksi HIV-HCV Di RSUP Sanglah Denpasar', Journal of Internal Medicine, 11(2).

Spach, D. (2017) HCV Incidence in the United States Definitions of HCV Incidence. Available at: https://www.hepatitisc.uw.edu/go/s creening-diagnosis/epidemiology- 
us/core-concept/all. (Accessed: 29 June 2020).

Surjadi, M. et al. (2011) 'Formal patient education improves patient knowledge of hepatitis $C$ in vulnerable populations', Digestive Diseases and Sciences. Springer, 56(1), pp. 213-219. doi: 10.1007/s10620010-1455-3.

Toshikuni, N., Arisawa, T. and Tsutsumi, M. (2014) 'Hepatitis C-related liver cirrhosis - strategies for the prevention of hepatic decompensation, hepatocarcinogenesis, and mortality', World Journal of Gastroenterology. WJG Press, 20(11), pp. 2876-2887. doi: 10.3748/wjg.v20.i11.2876.

Tsertsvadze, T. et al. (2020) 'Treatment outcomes of patients with chronic hepatitis $C$ receiving sofosbuvirbased combination therapy within national hepatitis $C$ elimination program in the country of Georgia', BMC Infectious Diseases. BioMed Central Ltd., 20(1). doi: 10.1186/s12879-019-4741-5.

WHO (2018) GUIDELINES FOR THE CARE AND TREATMENT OF PERSONS DIAGNOSED WITH CHRONIC HEPATITIS C VIRUS INFECTION. Available at: https://www.who.int/hepatitis/publ ications/hepatitis-c-guidelines2018/en/ (Accessed: 21 December 2019).

Wulandari, P. M. and Mulyantari, N. K. (2016) 'GAMBARAN HASIL SKRINING HEPATITIS B DAN HEPATITIS C PADA DARAH DONOR DI UNIT DONOR DARAH PMI PROVINSI BALI', EJurnal Medikal, 5(7). Available at: https://ojs.unud.ac.id/index.php/eu m/article/view/21561 (Accessed: 23 December 2019).

Younossi, Z. M., Birerdinc, A. and Henry, L. (2016) Hepatitis C infection: A multifaceted systemic disease with clinical, patient reported and economic consequences, Journal of Hepatology. doi: 10.1016/j.jhep.2016.07.005. 